удк 338.47(477)

DOI: https://doi.org/10.32851/2708-0366/2021.10.2

Кононов С.О.

аспірант,

Донецький державний університет управління

ORCID: https://orcid.org/0000-0002-5998-0029

Kononov Serhii

Donetsk State University of Management

\title{
ДОСЛІДЖЕННЯ ДОРОЖНЬОЇ ГАЛУЗІ УКРАЇНИ ТА ПЕРСПЕКТИВИ ІІІ РОЗВИТКУ
}

\section{RESEARCH OF THE ROAD INDUSTRY OF UKRAINE AND PROSPECTS OF ITS DEVELOPMENT}

У статті визначено головного суб 'єкта дорожньої галузі та напрями його діяльності. Зазначено структуру дорожньої галузі. Наведено порівняльну характеристику функціонування дорожньої галузі до та після реформ 2018 р. Розкрито основні проблеми дорожньої галузі, які потребують нових перетворень. Визначено особливості діяльності Державного дорожнього фонду. Представлено механізм фінансування дорожньої галузі Украӥни з 1 січня 2018 р. Підкреслено, шо трансформація дорожньої галузі України базується на Європейських нормах і принципах та за підтримки Європейського банку реконструкиї та розвитку. Проаналізовано основні стратегічні напрями поліпшення та розвитку галузі: боротьба з корупиією, діджиталізація, якість. Охарактеризовано передумови та особливості створення Всеукраӥнського дорожнього консориуіму.

Ключові слова: дорожня галузь, Державне агентство автомобільних доріг, Державний дорожній фонд, стратегія розвитку, корупція, діджиталізація, якість, Всеукраӥнський дорожній консоризіум.

В статье определень главный субъект дорожной отрасли и направления его деятельности. Указана структура дорожной отрасли. Приведена сравнительная характеристика функиионирования дорожной отрасли до и после реформ 2018 г. Раскрыты основныле проблемы дорожной отрасли, требуюшие новых преобразований. Определень особенности деятельности Государственного дорожного фонда. Представлен механизм финансирования дорожной отрасли Украины с 1 января 2018 г. Подчеркнуто, что трансформация дорожной отрасли Украинь базируется на Европейских нормах и принципах и при поддержке Европейского банка реконструкции и развития. Проанализированы основные стратегические направления улучшения и развития отрасли: борьба с коррупцией, диджстализация, качество. Охарактеризовань предпосылки и особенности создания Всеукраинского дорожного консоричима.

Ключевые слова: дорожная отрасль, Государственное агентство автомобильных дорог, Государственный дорожный фонд, стратегия развития, коррупция, диджитализацчия, качество, Всеукраинский дорожный консорцииум.

Effective functioning and development of the road industry is a strategic direction for any country. The relationship between other industries and enterprises that shape the country's economy depends on the activities of this industry. In order to make successful management decisions in the road industry, it is necessary to constantly monitor its condition. Therefore, the aim of the article is to determine the current trends in the functioning of the road industry of Ukraine. During the writing of the article, such research methods as theoretical were used; empirical (observations, comparisons); complex (analysis, synthesis, deduction, induction). The article identifies the main subject of the road industry and its activities. The structure of road economy is specified. A comparative description of the functioning of the road industry before and after the 2018 reforms is revealed. The main problems of the road industry that need new transformations have been identified, for example: ensuring short-, medium- and long-term road development planning; improving the quality and durability of roads on the basis of design 
and estimate documentation and conclusions of the feasibility study; increasing the share of paved public roads, etc. The peculiarities of the activity of the State Road Fund are determined. The mechanism of financing the road economy of Ukraine from January 1, 2018 is presented. It is emphasized that the transformation of the road industry of Ukraine is carried out on the basis of European norms and principles and with the support of the European Bank for Reconstruction and Development. The main strategic directions of improvement and development of the industry are analyzed: corruption, digitalization, quality. Prerequisites and features of creation of the All-Ukrainian road consortium are described. The presented materials of the article can be the basis of further research of the peculiarities of the functioning of the road industry of Ukraine and be used as a practical material for management decisions and the formation of an effective mechanism for further development of this industry.

Key words: road industry, State Agency of Motor Roads, State Road Fund, development strategy, corruption, digitalization, quality, All-Ukrainian Road Consortium.

Постановка проблеми. Дорожня галузь є однією зі стратегічно важливих галузей будь-якої країни. Від іiі стану та напрямів розвитку залежить економічне зростання країни та підвищується ії конкурентоспроможність на світовому просторі. Тому в часи великих реформаторських перетворень в Україні трансформаційні процеси торкнулися і дорожньої галузі. Як це відбувалося, які управлінські рішення було прийнято у дорожній галузі та які подальші перспективи ії розвитку сьогодні є дуже актуальним та своєчасним питанням, яке потребує системного аналізу.

Аналіз останніх досліджень і публікацій. Стан дорожньої галузі України та перспективи іï розвитку є актуальним напрямом досліджень багатьох науковців, серед яких: А. Безуглий, А. Гринько, В. Козак, О. Назаркевич, О. Святець, О. Солодовнік, О. Жулін, І. Токар та ін. Однак, ураховуючи швидкоплинність змін, які відбуваються у дорожній галузі, виникає потреба постійного моніторингу її розвитку.

Формулювання цілей статті. Мета статті - визначення сучасного стану та напрямів розвитку дорожньої галузі України.

Виклад основного матеріалу. Сьогодні одним із головних суб'єктів дорожньої галузі є Державне агентство автомобільних доріг України (Укравтодор), яке реалізує державну політку у сфері дорожнього господарства, діяльність котрого спрямовується і координується Кабінетом Міністрів України через міністра інфраструктури. У цілому структура дорожньої галузі є досить складною, яка містить не лише дороги та дорожні мережі, а й підприємства різних форм власності. Під час активного впровадження децентралізації дорожня галузь також зазнала деяких змін (рис. 1).

Аналіз рис. 1 показує, що з 1 січня 2018 р. у дорожній галузі відбулися зміни за всіма напрямами: управління, виконання дорожніх робіт, фінансування, контроль. Так, функції управління виконують не лише Укравтодор та Служба автомобільних доріг, а й Управління автодоріг, яке підпорядковане органам місцевої влади. Своєю чергою, виконання дорожніх робіт здійснюється не тільки державними підприємствами, а й іншими підприємствами різних форм власності. Відповідно до новацій, фінансування здійснюється тільки через дорожній фонд. А функції контролю розподілено між Державною аудиторською службою та ДП «НТЦ «Державний контроль якості».

Окрім того, напрями розвитку дорожнього господарства України закріплено й у Національній транспортній стратегії України на період до 2030 р., яка була схвалена в 2018 р. і визначає загальні проблеми у дорожньому господарстві, що потребують розв'язання [1]:

забезпечення коротко-, середньо- та довгострокового планування розвитку автомобільних шляхів;

визначення ключових показників ефективності управління дорожнім господарством та системи моніторингу їх виконання; уведення європейських стандартів проєктування, розроблення та обслуговування автомобільних доріг, підвищення рівня якості автодорожнього покриття та обгрунтованість вибору його типу, зокрема шляхом поступового відновлення експлуатаційних характеристик дорожньої мережі; 
поліпшення якості та довговічності автомобільних доріг на основі проєктно-кошторисної документації та висновків техніко-економічного обгрунтування;

збільшення частки автомобільних доріг загального користування 3 твердим покриттям;

розбудова мережі пунктів дорожнього сервісу для забезпечення проведення перевірки дотримання вимог режимів праці та відпочинку водіїв відповідно до Європейської угоди щодо роботи екіпажів транспортних засобів, які виконують міжнародні автомобільні перевезення;

упровадження довгострокових контрактів з експлуатаційного утримання автомобільних доріг на основі їх роботи та кінцевих результатів;

збільшення кількості пересувних габаритновагових комплексів та забезпечення здійснення дієвого контролю за перевищенням габаритновагових параметрів транспортних засобів.

Важливим аспектом у системі реформування дорожньої галузі є побудова ефективного механізму фінансування, яке забезпечувало би потреби як на рівні держави, так і на місцевому рівні.

Сьогодні дорожня галузь динамічно реформується. Відповідно до законів України «Про внесення змін до Бюджетного кодексу України щодо удосконалення механізму фінансового забезпечення дорожньої галузі» № 1763-19 від 17.11.2016 [2; 5] та «Про внесення змін до Закону України «Про джерела фінансування дорожнього господарства України» № 1762-19 від 17.11.2016 [3; 5], з 01.01.2018 у складі спеціального фонду Державного бюджету України розпочав роботу Державний дорожній фонд. Кошти дорожнього фонду спрямовуються виключно на будівництво, реконструкцію, ремонт і утримання автомобільних доріг загального користування, зокрема у вигляді субвенцій місцевим бюджетам, а також на заходи безпеки дорожнього руху. Одним 3 основних завдань роботи фонду є покращення фінансування ремонту місцевих доріг, які відповідно до Закону України «Про внесення змін до деяких законів України щодо реформування системи управління автомобільними дорогами загального користування» № 1764-19 від 17.11.2016 [4; 5] у 2018 р. передано зі сфери управління Укравтодору у сферу повноважень місцевих державних адміністрацій.

Отже, у процесі децентралізації дорожньої галузі з 01.01.2018 близько 120 тис км доріг передано облдержадміністраціям (ОДА), які забезпечують на території області реалізацію державної політики в галузі дорожнього господарства, вносять пропозиції щодо виробництва продукції й розробляють проэкти програм розвитку дорожнього господарства (рис. 2) [5].

Далі проаналізуємо детальніше напрями розвитку дорожньої галуззі, які сформовано на період 2021-2023 pр. Загальні зміни у дорожній галузі пов'язані з трансформацією системи управління, яка базується на Європейських нормах та принципах. Також низка заходів щодо розвитку дорожньої галузі формуэться за підтримки Європейського банку реконструкції та розвитку (СБРР).

Отже, основні зміни (плани) на період 2021-2023 рр. такі:

1. Заходи щцодо попередження корупиї̈:

- упровадження плану антикорупційних заходів у рамках проєкту з СБРР;

- переведення усієї тендерної документації в електронний формат;

- створення відкритих реєстрів АБЗ та калькулятору розрахунку досвіду підрядника; $[6 ; 7]$.

- лібералізація ціноутворення - від етапу преекту до звітування за виконані роботи

Окрім цього, ПрАТ «ДАК «Автомобільні дороги України» вже отримало Наглядову раду, розпочало співпрацю 3 «Прозорро» та розробило стратегію розвитку з фокусом на попередження корупції [6]. 


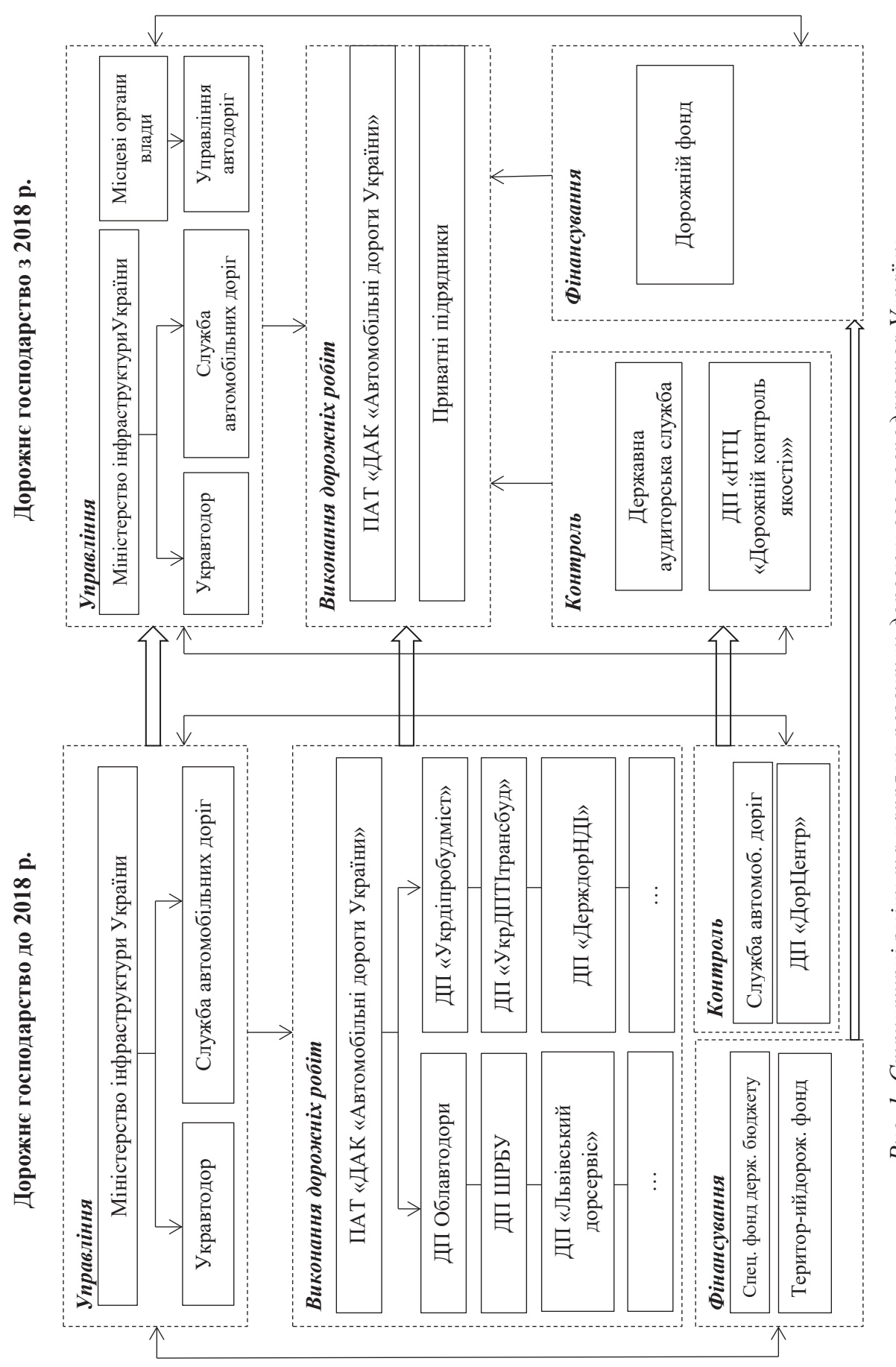

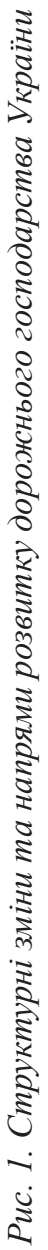




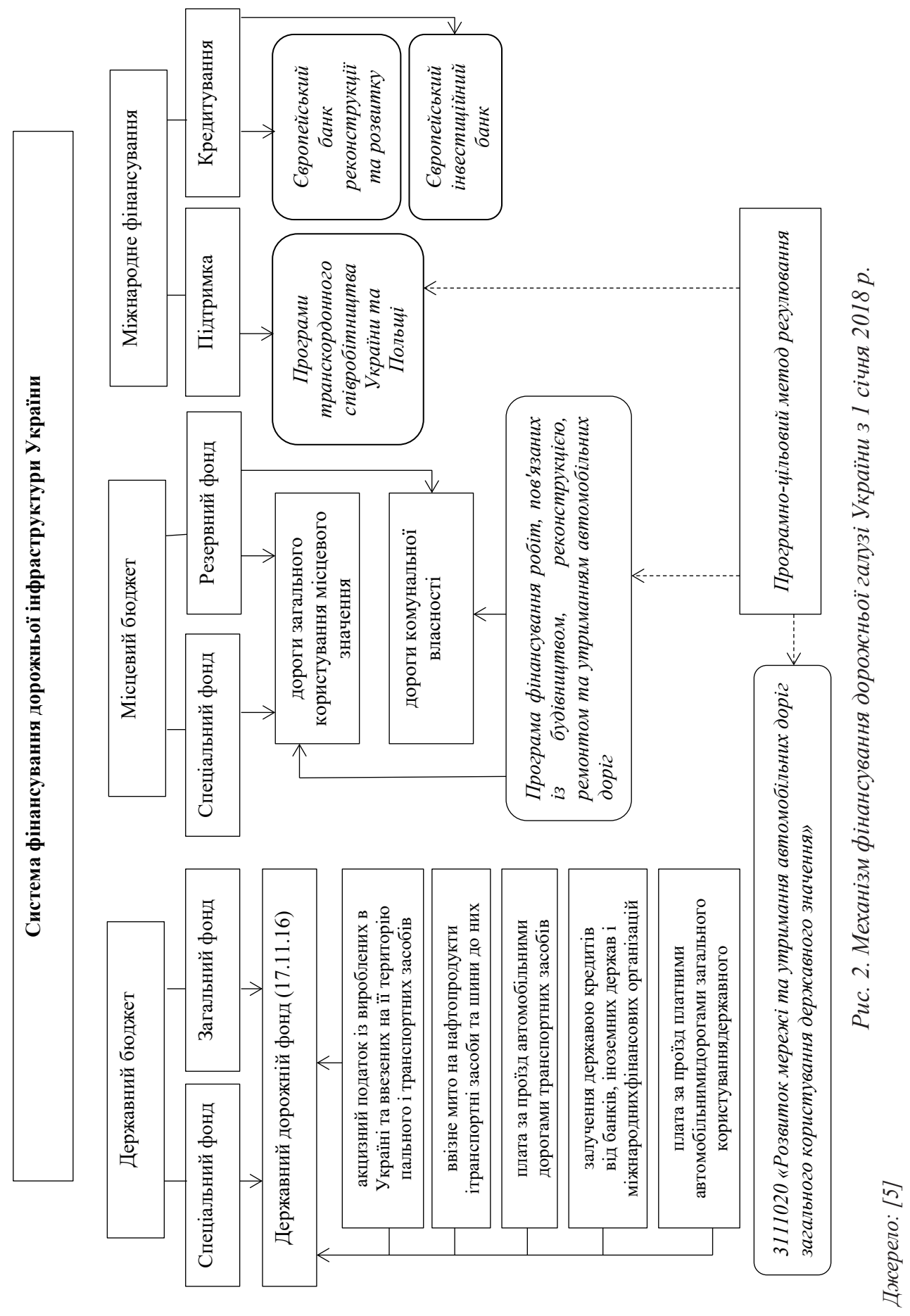


Діджиталізаиія дорожньої галузі.

У межах програми щодо діджиталізації галузі створено єдину інформаційну платформу E-road (електронна дорога). Вона поєднує інтерактивну карту дорожніх робіт із зазначенням фактичного стану робіт та їхніх виконавців, базу інших даних та систему звітності [8].

Систему, яка може акумулювати та систематизувати такий значний масив інформації, представили спеціалісти державного підприємства «Галузевий центр цифровізації та кібербезпеки». Проєкт Didgital Road був розроблений ГЦЦК у рамках виконання Міністерством інфраструктури України своїх зобов'язань згідно з Національним планом дій ініціативи «Партнерство «Відкритий Уряд» на 2021-2022 рр., затвердженим Розпорядженням КМУ від 24.02.2021 № 149. За словами розробників ресурсу, першим завданням, яке вирішуватиме система, буде запровадження єдиної для всіх балансоутримувачів цифрової моделі паспорту дороги, яка відповідатиме чинному СОУ та паспортизація всіх доріг за новим універсальним форматом [9].

Іншою розробкою ІТ-спеціалістів, представленою в ході заходу, став проєкт «Система управління інфраструктурними будівельними проєктами» (СУІП). Метою проєкту є автоматизація управління інфраструктурними проєктами, що реалізовуються за публічні кошти, а також контроль за виконанням робіт із планування, проєктування, будівництва та експлуатації інфраструктурних об'єктів, використанням бюджетних коштів у режимі реального часу [9].

2. Удосконалення системи якості.

Незважаючи на зростання кількості побудованих та відремонтованих робіт, відбувається зростання кількості скарг щодо їхньої якості, тому сьогодні сформовано та впроваджується нова система управління якістю.

Це система, яка забезпечує збір та аналіз даних про стан доріг та якість робіт, які використовуються для забезпечення високих експлуатаційних характеристик доріг на всіх етапах життєвого циклу дорожнього проєкту [10].

До недоліків попередньої системи управління якістю можна віднести такі:

- відсутній механізм моніторингу чинників дефектів та механізм уникнення їх у майбутньому;

- відсутня єдина база даних щодо якості доріг;

- відсутня судова практика щодо відшкодування наслідків неякісних доріг.

Отже, до основних суб'єктів, які впливають на якість у дорожній галузі, належать:

- Укравтодор САД - забезпечує належну якість робіт з проєктування, будівництва, реконструкції, ремонту й утримання автомобільних доріг загального користування;

- Проєктант - підготовка проєктної документації, на підставі якої здійснюється будівництво;

- Технічна рада - розгляд проєктних і технічних пропозицій;

- Дор'якість - моніторинг якості дорожніх робіт, моніторинг стану дорожньої мережі;

- Підрядник - забезпечення належної якості будівництва відповідно до проєкту; виконання внутрішнього нагляду, у тому числі шляхом залучення інженерів технічного нагляду; забезпечення гарантійного строку експлуатації об'єкта;

- Інженери технічного нагляду - виконання робіт із технічного нагляду у складі САД, виконавця робіт, незалежних організацій;

- Держдор НДІ - науково-технічне, дослідне, нормативно-методичне й інформаційне забезпечення проєктування, будівництва та експлуатації доріг; орган сертифікації; головний випробувальний центр;

- Громадський контроль - здійснення незалежного контролю [10].

На рис. 3 представлено етапи механізму управління якістю у дорожній галузі.

Таким чином, з рис. 3 видно, що управління якістю у дорожній галузі відбувається протягом всього життєвого циклу, тобто від аналізу дійсного стану до експлуатаційного утримання об’єктів дорожньої галузі. Також у межах 3-6-го етапів відбувається 


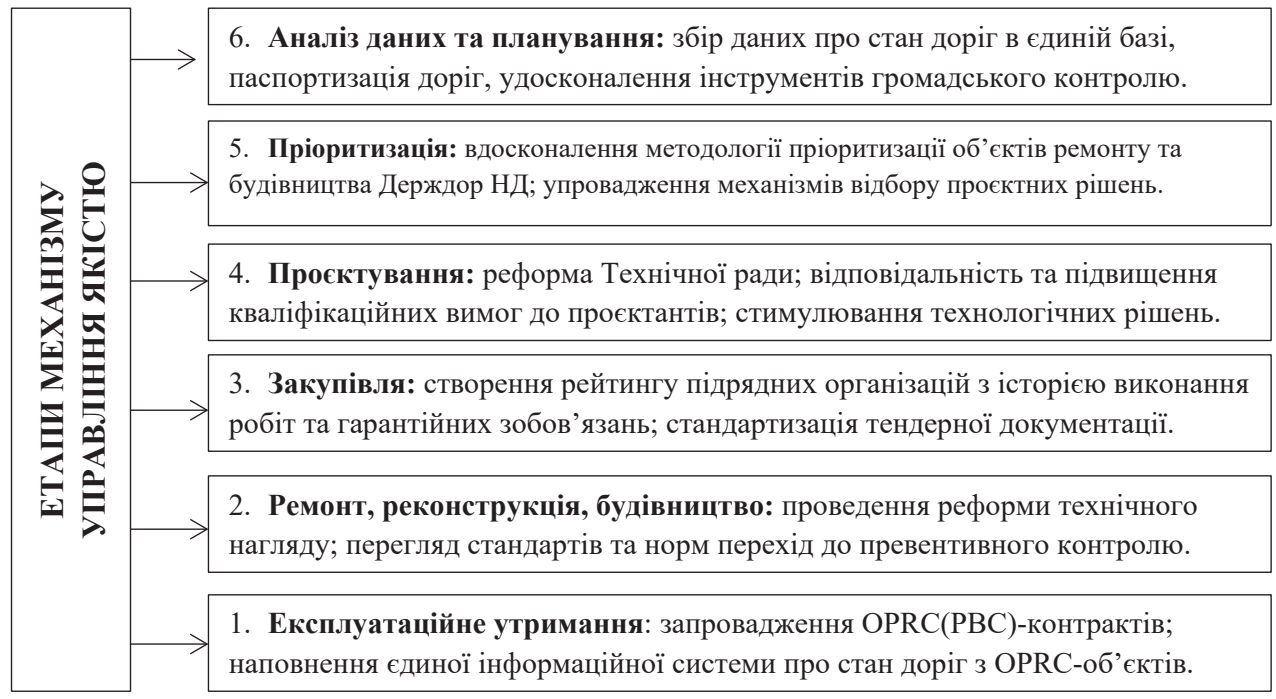

Рис. 3. Етапи механізму управління якістю у дорожній галузі

Джерело: складено автором за [10]

процес лібералізації ціноутворення. Відповідно, до всіх етапів здійснюється аудит системи та реформування дозвільної системи.

Суттєвою зміною у дорожній галузі стало створення Всеукраїнського дорожнього консорціуму. Так, починаючи з 2020 р. дорожні компанії почали створювати консорціуми, щоб об'єднувати власний досвід виконання договорів та мати змогу претендувати на об'ємні фінансові закупівлі. Адже за новими вимогами до участі у тендерних закупівлях компаніям необхідно відповідати за багатьма показниками - від підтвердження аналогічного досвіду до матеріально-технічної відповідності.

Отже, метою створення Всеукраїнського дорожнього консорціуму є реалізація масштабних інфраструктурних дорожніх проєктів.

На старті до Консорціуму увійшли вісім провідних дорожніх компаній, які прагнуть будувати українські дороги, мають для цього позитивний досвід та матеріальну базу (ПП «АВТОМАГІСТРАЛЬ», ПП «НВФ «МостопроєкТ», ТОВ «РоадКонстракшн», ТОВ «СТІ», ДП «Екранбуд» ТОВ «Екран», ТОВ «Луцька ДПМК», ТОВ «АБЗ-1, ТОВ «Трініті Груп»). Але сьогодні в складі консорціуму вже 11 компаній, на початку року до них приєдналися ще три компанії (ТОВ «Данко», ТОВ «Стройспецтехника» та ТОВ «БГ Комфорттаун»). У складі Консорціуму є учасники, які працюють на ринку з 1995 р. [11].

Сьогодні Консорціум об'єднує: технічний потенціал (1 520 одиниць дорожньо-будівельної техніки), 20 асфальтно-бетонних заводів, працівників (1 806 штатних працівників), досвід (10,5 млрд грн - сума контрактів як генпідрядника з 2018 до 2020 р.), фінансову спроможність (4,3 млрд грн - загальний грошовий оборот за 2020 р.).

Висновки. Таким чином, дорожня галузь України починаючи з 2018 р. динамічно розвивається та має позитивні трансформаційні перетворення. Основні зміни відбуваються у розподілі повноважень між державою та місцевим самоврядуванням. Головними аспектами, на які звернуто увагу у процесі розроблення стратегічних напрямів розвитку дорожньої галузі, є: боротьба з корупцією, цифровізація галузі та якість системи управління, яка призводить до поліпшення побудованих та відремонтованих доріг. Зміни у законодавчій базі призвели до можливості створення Всеукраїнського дорожнього консорціуму. Перспектива подальших досліджень полягає в аналізі ефективності стратегічних напрямів розвитку дорожньої галузі, які були розроблені на період 2021-2023 pp. 


\section{Список використаних джерел:}

1. Токар I.I. Сучасний стан та тенденції розвитку дорожнього господарства України. Проблеми і перспективи розвитку підприємництва. 2019. № 1. С. 153-163.

2. Про внесення змін до Бюджетного кодексу України щодо удосконалення механізму фінансового забезпечення дорожньої галузі : Закон України від 17.11.2016 № 1763-19. Законодавство України. URL: http://zakon5.rada.gov.ua/laws/show/1763-19429.

3. Про внесення змін до Закону України «Про джерела фінансування дорожнього господарства України» : Закон України від 17.11.2016 № 1762-19. Законодавство Украӥни. URL: http://zakon3.rada.gov.ua/laws/show/1762-19

4. Про внесення змін до деяких законів України щодо реформування системи управління автомобільними дорогами загального користування : Закон України від 17.11.2016 № 1764-VIII. Законодавство України. URL: http://zakon3.rada.gov.ua/laws/show/en/1764-19 428

5. Назаркевич О.Б. Механізм управління дорожнім господарством України в умовах децентралізації. Економіка та управління національним господарством. 2018. Вип. 4(132). С. 27-32.

6. Укравтодор презентував трирічний план реформування галузі. URL: https://www.ukrinform.ua/ rubric-economy/3215094-ukravtodor-prezentuvav-triricnij-plan-reformuvanna-galuzi.html

7. За правилами ЄС. Голова Укравтодору представив трирічний план реформ дорожньої галузі. URL: https://bereg-rda.gov.ua/2021/03/za-pravilami-ies-golova-ukravtodoru-pr/

8. Нові шляхи дорожньої галузі. URL: https://ukurier.gov.ua/uk/articles/novi-shlyahidorozhnoyi-galuzi/

9. Дорожня галузь «у цифрі». Мінінфраструктури створює нові цифрові інструменти для якісного управління. URL: https://mtu.gov.ua/news/32749.html

10. Укравтодор впровадить систему управління якістю у дорожній галузі. URL: https://ukravtodor. gov.ua/press/news/ukravtodor_vprovadyt systemu_upravlinnia_yakistiu_u_dorozhnii_haluzi.html

11. Гринько А. Всеукраїнський дорожній консорціум - новий етап розвитку дорожньої галузі. URL: https://vda.org.ua/vseukrainskij-dorozhnij-konsorcium-novij-etap-rozvitku-dorozhnoigaluzi-artem-grinenko/

\section{References:}

1. Tokar I.I. (2019). Suchasnyj stan ta tendenciyi rozvytku dorozhnogo gospodarstva Ukrayiny. Problemy i perspektyvy rozvytku pidpryyemnycztva, no. 1, pp. 153-163.

2. Pro vnesennya zmin do Byudzhetnogo kodeksu Ukrayiny shhodo udoskonalennya mexanizmu finansovogo zabezpechennya dorozhnoyi galuzi: Zakon Ukrayiny vid 17.11.2016 r. no. 1763-19. Zakonodavstvo Ukrayiny. Available at: http://zakon5.rada.gov.ua/laws/show/1763-19429

3. Pro vnesennya zmin do Zakonu Ukrayiny «Pro dzherela finansuvannya dorozhnogo gospodarstva Ukrayiny»: Zakon Ukrayiny vid 17.11.2016 r. no. 1762-19. Zakonodavstvo Ukrayiny. Available at: http://zakon3.rada.gov.ua/laws/show/1762-19

4. Pro vnesennya zmin do deyakyx zakoniv Ukrayiny shhodo reformuvannya systemy upravlinnya avtomobilnymy dorogamy zagalnogo korystuvannya: Zakon Ukrayiny vid 17.11.2016 r. no. 1764-VIII. Zakonodavstvo Ukrayiny. Available at: http://zakon3.rada.gov.ua/laws/show/en/1764-19 428

5. Nazarkevych O. (2018) Mexanizm upravlinnya dorozhnim gospodarstvom ukrayiny v umovax decentralizaciyi. Ekonomika ta upravlinnya nacionalnym gospodarstvom, vol. 4(132), pp. 27-32.

6. Ukravtodor prezentuvav tryrichnyj plan reformuvannya galuzi. Available at: https://www.ukrinform. ua/rubric-economy/3215094-ukravtodor-prezentuvav-triricnij-plan-reformuvanna-galuzi.html

7. Za pravylamy YeS. Golova Ukravtodoru predstavyv tryrichnyj plan reform dorozhnoyi galuzi. Available at: https://bereg-rda.gov.ua/2021/03/za-pravilami-ies-golova-ukravtodoru-pr/

8. Novi shlyaxy dorozhnoyi galuzi. Available at: https://ukurier.gov.ua/uk/articles/novi-shlyahidorozhnoyi-galuzi/

9. Dorozhnya galuz «V cyfri». Mininfrastruktury stvoryuye novi cyfrovi instrumenty dlya yakisnogo upravlinnya. Available at: https://mtu.gov.ua/news/32749.html

10. Ukravtodor vprovadyt systemu upravlinnya yakistyu u dorozhnij galuzi. Available at: https://ukravtodor.gov.ua/press/news/ukravtodor_vprovadyt_systemu_upravlinnia_yakistiu_u_ dorozhnii haluzi.html

11. Grynko A. Vseukrayinskyj dorozhnij Konsorcium - novyj etap rozvytku dorozhnoyi galuzi. Available at: https://vda.org.ua/vseukrainskij-dorozhnij-konsorcium-novij-etap-rozvitku-dorozhnoigaluzi-artem-grinenko/ 